\title{
Physicochemical characteristics of beer with rice nuruk
}

\author{
Kang Sun-a $^{1} \cdot$ Kwon Ye-seul $^{1} \cdot$ Jeong Seok-tae $^{1} \cdot$ Choi Han-seok $^{1} \cdot$ Im Bo-ra $^{1}$. \\ Yeo Su-hwan ${ }^{1} \cdot$ Kang Ji-eun $^{1}$ (D)
}

Received: 21 April 2020 / Accepted: 21 August 2020 / Published Online: 30 September 2020

(C) The Korean Society for Applied Biological Chemistry 2020

\begin{abstract}
Beer production with rice or other malt substitutes suffers from a lack of suitable enzymes for saccharification. For this reason, rice nuruk (fermentation starter) was tested as a starch replacement for malt in the saccharification process of beer production. The results of this study show that the enzyme activities of rice nuruk made with brewing fungi were higher than those of malt. Saccharification and glucoamylase activities were high in Aspergillus awamori KCCM 30790 and $\alpha$-amylase activity was high in Aspergillus oryzae CF1003. Overall, malt beer had significantly higher alcohol, $\mathrm{pH}$, total acid, volatile acids, amino acids, free amino nitrogen, bitterness unit and $\Delta \mathrm{E}$ than rice nuruk beer. Where as Aspergillus awamori KCCM 30790 beer had significantly higher soluble solids, reducing sugar than malt beer. According to a sensory evaluation, malt beer was better color, flavor and Aspergillus oryzae CF1003 beer was better taste, texture, overall acceptability than other beer. Therefore Aspergillus awamori KCCM 30790 beer was suitable considering enzyme activities (saccharification, glucoalmylase) and physicochemical characteristics (soluble solids, reducing sugar). And then Aspergillus oryzae CF1003 beer was suitable considering sensory evaluation (taste, texture, overall acceptability). Therefore rice nuruk like Aspergillus awamori KCCM 30790 and Aspergillus oryzae CF1003 were suitable as a substitute material that can replace for malt in beer proceccing.
\end{abstract}

Keywords Beer $\cdot$ Fungi $\cdot$ Malt $\cdot$ Rice nuruk $\cdot$ Saccharification

Kang Ji-eun $(\bowtie)$

E-mail:kje0516@korea.kr

${ }^{1}$ National Institute of Agricultural Sciences, Nongsaengmyeong-ro 166, Wanju, Jeollabukdo, Republic of Korea

This is an Open Access article distributed under the terms of the Creative Commons Attribution Non-Commercial License (http://creativecommons. org/licenses/by-nc/3.0/) which permits unrestricted non-commercial use, distribution, and reproduction in any medium, provided the original work is properly cited.

\section{Introduction}

Beer is one of the oldest beverages in recorded history, with the first records appearing from around 4000 BCE. The drink is a representative product based on a two-step fermentation process that involves the preparation of a saccharified solution using malts, hops, and water before fermenting the solution using yeast [1]. Koreans showed a significant amount of beer consumption; according to the National Tax Service statistics, the size of the domestic Korean beer market accounted for $51.4 \%$ of the total shipped volume of liquor in 2017 [2], representing the highest percentage of all shipped liquors.

Meanwhile, there has been a recent boom in beer importation in Korea, with an annual average rate of $23.2 \%$ [3]. Lager-type beers account for a vast majority of Korean beer sales at $95 \%$, which is substantially higher than the $5 \%$ sales provided by ale-type beers. The recent increase in the demand for imported beer has resulted in a more diversified market. Moreover, the revision of the 2014 Liquor Tax Act enabled the sale of beer from the small-scale craft beer manufacturing industry. These circumstances have provided a wider variety of selection for consumers, accompanied by an increased interest in brewing beer, which can satisfy various personal preferences $[1,4]$.

Beer is manufactured after saccharifying starch, the main component of grains. The saccharification process is one of the most important factors influencing the taste and quality of beer because the degree of saccharification determines the beer's sugar and alcohol content [5]. Malt, the main ingredient of beers, contains starch-hydrolyzing enzymes, thereby facilitating beer production through natural enzyme activities [4]. Rice is often used as a substitute for starch because of its soft texture and dry taste [2]. However, substituting starch with rice as a supplementary ingredient introduces several hurdles in the saccharification and filtration processes because rice lacks the starch-hydrolyzing enzymes that come from malts. As a result, it is difficult to obtain the required quality of wort, the saccharified solution made from adding water to malt, which is vital to the process. Therefore, the 
addition of commercial enzyme formulations is required to compensate for the lack of enzymes used in preparing the wort with rice [6,7].

Nevertheless, if beer makers use domestic surplus rice instead of imported malt as raw material, it will help boost domestic agricultural consumption. Rice beer also has the advantage of being able to produce beer products with various flavors in the unified malt beer industry. Previous studies have investigated the application of various supplementary ingredients in beer production, including the addition of various starch-hydrolyzing enzymes [8]. One study investigated the production of beers using gokja, a traditional type of nuruk, or fermentation starter [1].

The present study aimed to use enzymes produced by microorganisms with the addition of rice nuruk in beer production. In doing so, this research also aimed to simultaneously resolve the problem of low enzyme activities when substituting malts with rice and the problem of increasing surplus rice in Korea. Rice nuruk is widely used for fermentation and is made by cultivating and drying steamed rice with inoculated fungi for brewing [8,9]. Furthermore, rice nuruk is rich in various starch-hydrolyzing enzymes and has been shown to play a role in inducing efficient saccharification and fermenting alcohol, providing the primary source of flavor and taste to liquors [9]. Recent studies have attempted to produce a new type of product like syrup and salt, by combining rice nuruk as an enzymatic agent of the grain starch $[8,9]$.

Moreover, rice nuruk as a supplementary ingredient and enzymatic agent of beers would resolve the challenge of consuming surplus domestic agricultural products while offering a wide variety of beer preferences to meet the increasing consumer demand [10]. Toward this end, a high-quality rice beer was prepared by adding rice nuruk with various fungal strains during the saccharification process. The characteristics that determine the taste and quality of the resulting rice beer were compared with those of traditional malt beer.

\section{Materials and Methods}

\section{Raw materials and fungal strains}

This study used rice nuruk from Samkwang rice harvested in 2017 at Yeongin Agricultural Cooperative Rice Processing Complex in Asan City, Chungcheongnam-do. The nuruk was prepared using two commercial fungal strains (Aspergillus oryzae CF1003 (A. oryzae CF1003) and Aspergillus luchuensis CF1005 (A. luchuensis CF1005)) obtained from Chungmoo Fermentation Co. Ltd., six strains (Aspergillus usamii KCTC 6954-6959 (A. usamii KCTC 6954-6959)) distributed from the Korea Collection for Type Cultures, and two strains (Aspergillus awamori KCCM 32790 and KCCM 60247 (A. awamori KCCM 32790 and KCCM 60247)) distributed from the Korean Culture Center of Microorganisms. For comparison, beers made with pilsner malt (Pilsner, Weyermann,
Germany), hops (Cascade, Brewferm, Beverlo, Belgium), and aletype yeast (Safale S-04, Bision Co., Sungnam, Korea) were also created for the study.

\section{Preparation of the nuruk seed}

The rice was washed thoroughly and immersed in water for $2 \mathrm{~h}$, and then the water was slowly drained for $1 \mathrm{~h}$ to give it time to absorb moisture to the center of the rice. After placing the rice in a steamer (MS-30, Yaegaki Food \& System Inc., Himeji, Japan), more steam was added to the rice for $60 \mathrm{~min}$ right after the first appearance of water vapor. The hard-steamed rice was left to cool, and then $200 \mathrm{~g}$ portions of rice were placed in conical flasks. The rice was then inoculated with the cultured strains, and cultivation was carried out in a nuruk fermentor (Mini 15, Yaegaki Co.) at 37 ${ }^{\circ} \mathrm{C}$ for 10 days until spore production.

\section{Preparation of rice nuruk}

For the preparation of the rice nuruk, $10 \mathrm{~kg}$ of rice was washed thoroughly and immersed in water for $2 \mathrm{~h}$, and then the water was drained for $1 \mathrm{~h}$. After placing the rice in a steamer (MS-30, Yaegaki Food \& System Inc.), hard-steamed rice was prepared by adding more steam to the rice for $40 \mathrm{~min}$ right after the first appearance of water vapor. The hard-steamed rice was cooled to $40{ }^{\circ} \mathrm{C}$, inoculated with the cultured strains, and cultivation was carried out in a nuruk fermentor (Mini 15, Yaegaki Co.) at $37^{\circ} \mathrm{C}$ for $48 \mathrm{~h}$. The finished nuruk was stored in a freezer for subsequent use.

\section{Enzyme activity determination}

Amylase and protease were activated using a Kikkoman brew analysis kit (Kikkoman Co., Tokyo, Japan) according to the manufacturer's instructions. Absorbance (the degree to which an object absorbs light) measurements set at $400 \mathrm{~nm}$ were carried out using a medical enzyme analyzer (Synergy MX, BioTek Instruments Inc., Winooski, VT, USA). Saccharogenic power was measured using a saccharogenic power kit (Kikkoman). One unit of saccharogenic power was defined as an activity that released $1 \mu \mathrm{mol} 4$-nitrophenol (pNP) from 4-nitrophenyl $\beta$-D-glucoside per minute at $37^{\circ} \mathrm{C}[11]$.

Glucoamylase and $\alpha$-glucosidase activities were measured using a glucose-forming activity fractional quantification kit (Kikkoman), and $\alpha$-amylase activity was determined using an $\alpha$-amylase measuring kit (Kikkoman). First, one unit of glucoamylase activity was defined as the activity that released $1 \mu \mathrm{mol}$ pNP from 4-nitrophenyl $\beta$-D-glucoside per minute at $37^{\circ} \mathrm{C}$. Second, one unit of $\alpha$-glucosidase activity was defined as the activity that released $1 \mu \mathrm{mol} \mathrm{pNP}$ from 4-nitrophenyl $\alpha$ glucoside per minute at $37{ }^{\circ} \mathrm{C}$. Third, one unit of $\alpha$-amylase activity was defined as the activity that released $1 \mu \mathrm{mol} 2$ chloro-4-nitrophenol from 2-chloro-4-nitrophenyl $6^{5}$-azido- $6^{5}$ deoxy- $\beta$-maltopentaoside per minute at $37^{\circ} \mathrm{C}$ [12].

Carboxy peptidase activities were measured using an acidic carboxy 
peptidase measuring kit (Kikkoman). One unit of carboxypeptidase activity was defined as the activity that released $1 \mu \mathrm{mol}$ carboxybenzomethyl-L-tyrosine-L-alanine per minute at $37{ }^{\circ} \mathrm{C}$ [13].

Acidic protease activity was determined by heating a mixture of $1.5 \mathrm{~mL}$ of casein (Junsei Chemical Co., Ltd., Tokyo, Japan) and $1.0 \mathrm{~mL}$ of $\mathrm{pH} 3.0 \mathrm{Mcllvaine}$ buffer for $5 \mathrm{~min}$ at $40^{\circ} \mathrm{C}$. Subsequently, $0.5 \mathrm{~mL}$ of the sample was added and allowed to react for $60 \mathrm{~min}$ at $40{ }^{\circ} \mathrm{C}$. After $3 \mathrm{~mL}$ of $0.4 \mathrm{M}$ trichloroacetic acid (Junsei Chemical Co., Ltd.) was added to remove the precipitate, $1 \mathrm{~mL}$ of this solution was mixed with $5 \mathrm{~mL}$ of $0.4 \mathrm{M} \mathrm{Na}_{2} \mathrm{CO}_{3}$ (SigmaAldrich Co., St. Louis, MO, USA) and $1 \mathrm{~mL}$ of phenol (SigmaAldrich Co.). The researchers maintained the temperature of the resulting solution at $40{ }^{\circ} \mathrm{C}$ for $30 \mathrm{~min}$ and measured its absorbance at $660 \mathrm{~nm}$. Blanks (blank value measured with distilled water) were prepared by heating a mixture of $1.5 \mathrm{~mL}$ of casein and 1.0 $\mathrm{mL}$ of $\mathrm{pH} 3.0 \mathrm{McIlvaine}$ buffer for $5 \mathrm{~min}$ at $40{ }^{\circ} \mathrm{C}$. then added 3 $\mathrm{mL}$ of $0.4 \mathrm{M}$ trichloroacetic acid, allowing it to react for $60 \mathrm{~min}$ at $40{ }^{\circ} \mathrm{C}$, and adding $0.5 \mathrm{~mL}$ of the rice nuruk sample to remove the precipitate. Further treatments were conducted, as described above [14].

Acidic protease activity $(\mathrm{U} / \mathrm{mL})$ was calculated using the formula: $y \times 6 / 1$ (amount of reaction solution) $\times 1 / 0.5(\mathrm{~V})$. The $y=(\mathrm{Es}-$ $\mathrm{Eb})$ is the tyrosine content based on a calibration curve, Es is the absorbance of the sample, Eb is the absorbance of the blank, and $\mathrm{V}$ is the sample volume added to the reaction well $(\mathrm{mL})$.

\section{Preparation of beer}

The researchers ground $500 \mathrm{~g}$ of malt and added it to a saccharification tank, along with $500 \mathrm{~g}$ of rice nuruk and $3 \mathrm{~L}$ of water. Saccharification was performed at $50{ }^{\circ} \mathrm{C}(15 \mathrm{~min})$, at $62{ }^{\circ} \mathrm{C}$ $(1 \mathrm{~h})$, at $72^{\circ} \mathrm{C}(15 \mathrm{~min})$, and at $78^{\circ} \mathrm{C}(15 \mathrm{~min})$. After completing saccharification, $3 \mathrm{~L}$ of water at $78^{\circ} \mathrm{C}$ was slowly poured into the mixture while filtering to recover the remaining sugar. The filtered wort was added into a brew kettle, and $0.1 \%$ (w/v) of hops was added when the solution started to boil. The mixture was allowed to boil for $1 \mathrm{~h}$ without closing the lid. The brew kettle was rapidly cooled to $38{ }^{\circ} \mathrm{C}$, and the mixture was transferred into a sterilized fermenter to inoculate $0.05 \%(\mathrm{w} / \mathrm{v})$ of dry yeast. The beer was fermented at $25{ }^{\circ} \mathrm{C}$ for eight days. At the end of fermentation, 800 $\mathrm{mL}$ of beer and $0.06 \%(\mathrm{w} / \mathrm{v})$ of sugar (CJ Cheiljedang Co., Incheon, Korea) were added to a $1 \mathrm{~L}$ pressure-resistant beer bottle, and the solution was further aged in a room maintained at $4{ }^{\circ} \mathrm{C}$ for 10 days $[1,7]$.

\section{Physicochemical characteristics of beer}

The $\mathrm{pH}$ was measured at room temperature through a $\mathrm{pH}$ meter (Orion 3 star, Thermo Fisher Scientific Inc., Waltham, MA, USA). Meanwhile, the sample acidity was determined by measuring the amount of $0.1 \mathrm{~N} \mathrm{NaOH}$ (Yakuri Pure Chemicals Co., Ltd., Kyoto, Japan) needed to neutralize $10 \mathrm{~mL}$ of the sample. The amino acid value was determined by mixing a sample of known acidity with $5 \mathrm{~mL}$ of formalin (Yakuri Pure Chemicals Co., Ltd.) and $0.1 \mathrm{~N}$
$\mathrm{NaOH}$ [15]. Free amino nitrogen (FAN) was quantitated with glycine (Junsei Chemical Co., Ltd., Tokyo, Japan) using the ninhydrin method [16]. The soluble solids (Brix) were measured three times using a portable digital refractometer (PR101, ATAGO $^{\circledR}$, Tokyo, Japan) [4]. A 3,5-dinitrosalicylic acid method was used to analyze reducing sugars using glucose as its standard [17]. The alcohol content was measured using an alcohol analyzer (DA-155, Kyoto Electronics MFG. Co., Ltd., Kyoto, Japan). The volatile acid content was determined from the acetic acid content by titrating $30 \mathrm{~mL}$ of the sample with $0.01 \mathrm{~N} \mathrm{NaOH}$ until reaching a $\mathrm{pH}$ of 8.2 [15].

The sample color was determined using Hunter values, scales for the accurate measurement of color. Lightness $(L)$, redness $( \pm a)$, and yellowness $( \pm \mathrm{b})$ values were determined using a colorimeter (Ultra Scan PRO, Hunter Lab Inc., Reston, VA, USA). The bitterness unit of the beer was analyzed based on the National Tax Service Regulations on Liquor Analysis [6].

\section{Sensory evaluation}

Sensory evaluation was conducted by a panel of six male researchers and ten female researchers (aged 25-50 yr) with sensory evaluator experience. The fragrance and taste of beer made with rice nuruk were given scores between 1 and 15 . The evaluations were conducted three times. The samples provided to the panel were labeled with random numbers according to a Williams Latin Square design, with intervals of 3-5 min between each sample evaluation [18].

\section{Statistical analysis}

The statistical significance of the experimental results was analyzed using Statistical Package for Social Sciences (SPSS Version 18.0, IBM, USA). All data were evaluated using a oneway analysis of variance (ANOVA) at a $5 \%$ significance level $(p<0.05)$.

\section{Results and Discussion}

\section{Enzyme activity of rice nuruk}

In beer processing, a saccharification solution is produced by converting starch into fermentable sugar by liquefying the enzymes produced by the malt, which is then subjected to an alcohol fermentation process [19]. During saccharification, $\alpha-$ amylase liquefies the starch, while glucoamylase breaks down the liquefied sugar and produces glucose [20].

In rice beer, however, the proportion of rice is increased instead of malt, which decreases the ratio of malt enzyme responsible for liquefaction and saccharification of starch. Rice beer uses commercial enzymes or nuruk microorganisms to compensate for the lack of malt enzymes [6,21]. Because this study aimed to produce beer using rice, rice nuruk made of $A$. oryzae, $A$. luchuensis, A. usamii and A. awamori were used instead of 
Table 1 Enzyme activities (U/g, dry base) of malt and rice nuruk made with brewing fungi

\begin{tabular}{|c|c|c|c|c|}
\hline Sample & Saccharification & $\alpha$-Amylase & Glucoamylase & Carboxypeptidase \\
\hline Malt & $232.14 \pm 2.45^{\mathrm{k} 1}$ & $320.82 \pm 0.06^{\mathrm{b}}$ & $143.18 \pm 6.78^{k}$ & $6,629 \cdot 17 \pm 51 \cdot 10^{\mathrm{i}}$ \\
\hline A. oryzae CF1003 & $3,506.13 \pm 1.18^{\mathrm{c}}$ & $401.45 \pm 1.14^{\mathrm{a}}$ & $3,429.53 \pm 0.45^{\mathrm{c}}$ & $72,392.62 \pm 15.04^{\mathrm{g}}$ \\
\hline A. luchuensis CF1005 & $2,708.55 \pm 0.90^{\mathrm{e}}$ & $65.72 \pm 42.59^{h}$ & $2,655.45 \pm 4.60^{d}$ & $2,4482.27 \pm 43.15^{\mathrm{h}}$ \\
\hline A. awamori KCCM 30790 & $3,925.13 \pm 189.13^{\mathrm{a}}$ & $281.39 \pm 2.22^{\mathrm{c}}$ & $3,909.70 \pm 170.53^{\mathrm{a}}$ & $10,6130.06 \pm 7.52^{d}$ \\
\hline A. awamori KCCM 60247 & $1,950.92 \pm 205.49^{\mathrm{h}}$ & $81.18 \pm 2.04^{\mathrm{g}}$ & $1772.57 \pm 203.84^{\mathrm{h}}$ & $103,789.29 \pm 1,323.25^{\mathrm{e}}$ \\
\hline A. usami КСТC 6954 & $2,744.58 \pm 475.99^{d}$ & $89.27 \pm 3.07^{\mathrm{f}}$ & $2,524.83 \pm 448.70^{\mathrm{e}}$ & $11,1895.11 \pm 455.83^{\mathrm{b}}$ \\
\hline A. usami КСТС 6955 & $2,382.99 \pm 459.39^{\mathrm{g}}$ & $46.03 \pm 1.21^{\mathrm{k}}$ & $2,203.40 \pm 486.08^{\mathrm{g}}$ & $74,288.53 \pm 125.05^{\mathrm{g}}$ \\
\hline A. usami КСТC 6956 & $2,653.28 \pm 774.52^{f}$ & $109.32 \pm 3.85^{\mathrm{d}}$ & $2,420.34 \pm 792.12^{\mathrm{f}}$ & $99,906.36 \pm 1,148.34^{\mathrm{f}}$ \\
\hline A. usami КСТC 6957 & $3,727.61 \pm 460.63^{b}$ & $92.90 \pm 0.85^{\mathrm{e}}$ & $3,488.88 \pm 497.60^{\mathrm{b}}$ & $106,201.44 \pm 895.04^{d}$ \\
\hline A. usami КСТC 6958 & $1,718.46 \pm 404.46^{\mathrm{i}}$ & $55.42 \pm 3.36^{\mathrm{j}}$ & $1,595.46 \pm 395.42^{\mathrm{i}}$ & $112,461.69 \pm 1,289.28^{c}$ \\
\hline A. usami КСТС 6959 & $969.67 \pm 250.41^{\mathrm{j}}$ & $60.79 \pm 4.19^{i}$ & $821.71 \pm 250.34^{j}$ & $125,095.66 \pm 752.26^{\mathrm{a}}$ \\
\hline
\end{tabular}

${ }^{1}$ Values are mean $\pm \mathrm{SD}(\mathrm{n}=3)$, different letters within the same column differ significantly $(p<0.05)$

commercially available enzymes.

The enzyme activities of malt and rice nuruk were first analyzed according to the different fungal strains used in the process. In terms of saccharogenic power and glucoamylase activity, the overall enzyme activity was significantly higher in rice nuruk compared to malt $(p<0.05)$ (Table 1$)$. The saccharogenic power of A. awamori KCCM 30790, possessing the highest enzyme activity at 3,925.13 U/g, dry base (the enzyme's strength per $1 \mathrm{~g}$ of nuruk) was approximately 16.9 times higher than that of malt, which had the lowest enzyme activity at $232.14 \mathrm{U} / \mathrm{g}$, dry base. A similar trend was observed for glucoamylase activity, which was the highest for A. awamori KCCM 30790 at 3,909.70 U/g, dry base. It was approximately 27.3 times higher than malt's lowest activity of $143.18 \mathrm{U} / \mathrm{g}$, dry base.

Glucoamylase can break down $\alpha$-1,4-glucan bonds, but unlike $\alpha$-amylase, it can hydrolyze liquefied starch from the nonreducing end to produce glucose and dextrin molecules of varying molecular weights. By contrast, $\alpha$-amylase irregularly hydrolyzes the internal $\alpha$-1,4-glucan bonds between amylose and amylopectin [20]. In other words, $\alpha$-amylase produces dextrin with low molecular weight and oligosaccharides. The $\alpha$-amylase does this by hydrolyzing starch during liquefying, resulting in a lower viscosity [7,22]. In the present study, the $\alpha$-amylase activity of $A$. usamii KCTC 6955 was the lowest (46.03 U/g, dry base), whereas A. oryzae CF1003 showed the highest activity $(401.45 \mathrm{U} / \mathrm{g}$, dry base). A. oryzae CF1003's $\alpha$-amylase activity is1.3times higher than malt's (320.82 U/g, dry base), suggesting that it is capable of rapidly liquefying starch. The enzyme activity of the proteolytic enzyme, carboxypeptidase, was significantly higher for the ricebased fermentation agents than for malt $(p<0.05)$. A. usamii KCTC 6959 had the highest carboxypeptidase activity at $125,095.66$ $\mathrm{U} / \mathrm{g}$, dry base, 18.9 times higher than malt, with the lowest carboxypeptidase activity at $6,629.17 \mathrm{U} / \mathrm{g}$, dry base. Given that all of the isolated microorganisms showed higher enzyme activity than malt, rice nuruk appears to be an appropriate material as a partial substitute for malt.

\section{Physicochemical characteristics of the beer}

Table 2 shows the physicochemical compositions of different beers. The alcohol content of beer was determined to range from $5.40 \%(\mathrm{v} / \mathrm{v})$ (A. awamori KCCM 30790) to $7.63 \%$ (v/v) (malts) and was thus significantly higher in malt beer $(p<0.05)$. The $\mathrm{pH}$ ranged from A. awamori KCCM 30790's 4.41 to malt's 4.68. The beer manufactured using both malt and rice nuruk fell within the $\mathrm{pH}$ range of conventionally fermented beers $[23,24]$. The beer's sour taste is based on its total acidity and is derived from acids produced during the yeast proliferation and fermentation processes $[1,23,25]$. The total acidity was the lowest with A. oryzae CF1003 at $0.12 \%(\mathrm{w} / \mathrm{v})$, but the difference from the others was not statistically significant $(p<0.05)$. The volatile acids in the beers mainly include acetic acid (20-150 mg/L) and formic acid (20-40 $\mathrm{mg} / \mathrm{mL}$ ), which are produced by the degradation of glucose [3]. In this study, the volatile acid content ranged from $25.67 \%(\mathrm{w} / \mathrm{v})$ (A. awamori KCCM 30790) to $35.20 \%$ (w/v) (malt), demonstrating significantly higher volatile acid levels in malt-based beer $(p<0.05)$.

Soluble solids were significantly higher in beer produced with A. awamori KCCM $30790\left(8.97^{\circ} \mathrm{Bx}\right)(p<0.05)$ compared to the others. The reducing sugar content, a monosaccharide with hemiacetal groups used as a nutrient source for microorganisms, was slightly higher in beers containing rice nuruk $(0.24-0.29 \%$ $(\mathrm{w} / \mathrm{v}))$ than in those containing only malt $(0.22 \%(\mathrm{w} / \mathrm{v}))$. The reducing sugar of the completed beer typically ranges from approximately 0.5 to $0.8 \%(\mathrm{w} / \mathrm{v})$, which was lower in this experiment. The high reducing sugar content in beers made using rice nuruk suggests that rice nuruk would be advantageous for yeast proliferation and alcohol production in beer manufacturing.

Approximately $50 \%(\mathrm{w} / \mathrm{v})$ of the amino acids present in beer serves as the nutrient source of yeast. The amount is then reduced using proteins and peptides in metabolic processes, and the remaining amino acids are present as components of beers [16]. The amino acid (glycine) content ranged from $7.90 \mathrm{~g} / 100 \mathrm{~mL}(A$. oryzae CF1003) to $8.97 \mathrm{~g} / 100 \mathrm{~mL}$ (A. awamori KCCM 30790). 
Table 2 Comparison of physiochemical characteristics in beer with rice nuruk

\begin{tabular}{|c|c|c|c|}
\hline & Malt & A. oryzae CF1003 & A. awamori KCCM 30790 \\
\hline Alcohol (v/v, \%) & $7.63 \pm 0.06^{\mathrm{a} 1}$ & $6.77 \pm 0.06^{\mathrm{b}}$ & $5.40 \pm 0.00^{c}$ \\
\hline $\mathrm{pH}$ & $4.68 \pm 0.01^{\mathrm{a}}$ & $4.48 \pm 0.02^{\mathrm{b}}$ & $4.41 \pm 0.01^{\mathrm{c}}$ \\
\hline Total acid (citric acid, \%) & $0.14 \pm 0.00^{\mathrm{b}}$ & $0.12 \pm 0.00^{\mathrm{c}}$ & $0.15 \pm 0.02^{\mathrm{a}}$ \\
\hline Volatile acid (mg/L) & $35.20 \pm 0.53^{\mathrm{a}}$ & $33.53 \pm 0.61^{\mathrm{b}}$ & $25.67 \pm 0.61^{\mathrm{c}}$ \\
\hline Soluble solids $\left({ }^{\circ} \mathrm{Bx}\right)$ & $8.53 \pm 0.06^{\mathrm{b}}$ & $7.90 \pm 0.00^{\mathrm{c}}$ & $8.97 \pm 0.06^{\mathrm{a}}$ \\
\hline Reducing sugar (\%) & $0.22 \pm 0.01^{\mathrm{c}}$ & $0.24 \pm 0.01^{\mathrm{b}}$ & $0.29 \pm 0.02^{\mathrm{a}}$ \\
\hline Amino acid (Glycine, g/100 mL) & $0.14 \pm 0.00^{\mathrm{a}}$ & $0.11 \pm 0.00^{\mathrm{b}}$ & $0.10 \pm 0.00^{\mathrm{c}}$ \\
\hline FAN (mg/L) & $362.06 \pm 3.45^{\mathrm{a}}$ & $281.71 \pm 2.55^{\mathrm{b}}$ & $265.54 \pm 1.40^{\mathrm{c}}$ \\
\hline $\mathrm{BU}$ & $8.78 \pm 0.32^{\mathrm{a}}$ & $7.93 \pm 0.28^{b}$ & $2.80 \pm 0.09^{c}$ \\
\hline $\operatorname{Lightness}^{2}\left(\mathrm{~L}^{*}\right)$ & $87.74 \pm 0.01^{\mathrm{c}}$ & $92.95 \pm 0.02^{\mathrm{a}}$ & $89.95 \pm 0.01^{\mathrm{b}}$ \\
\hline $\operatorname{Redness}^{3}\left(a^{*}\right)$ & $0.97 \pm 0.01^{\mathrm{b}}$ & $-0.48 \pm 0.01^{\mathrm{c}}$ & $1.45 \pm 0.02^{\mathrm{a}}$ \\
\hline Yellowness ${ }^{4}\left(b^{*}\right)$ & $27.94 \pm 0.02^{\mathrm{a}}$ & $23.31 \pm 0.00^{\mathrm{b}}$ & $20.38 \pm 0.01^{\mathrm{c}}$ \\
\hline$\Delta \mathrm{E}^{5}$ & $30.54 \pm 0.03^{\mathrm{a}}$ & $24.37 \pm 0.01^{\mathrm{b}}$ & $22.68 \pm 0.01^{\mathrm{c}}$ \\
\hline
\end{tabular}

${ }^{1)}$ Values are mean $\pm \mathrm{SD}(\mathrm{n}=3)$, different letters within the same column differ significantly $(p<0.05)$

${ }^{2)}$ Lightness $(0=$ white, $100=$ black $)$

${ }^{3)}$ Redness $(-=$ green, $+=$ red $)$

${ }^{4)}$ Yellowness $(-=$ blue, $+=$ yellow $)$

${ }^{5)} \Delta \mathrm{E}=\sqrt{\left(L_{\text {sample }}-L_{\text {standard }}\right)^{2}+\left(a_{\text {sample }}-a_{\text {standard }}\right)^{2}+\left(b_{\text {sample }}-b_{\text {standard }}\right)^{2}}$

The protein content of malts should be relatively low and homogeneous because the polymer protein has a high viscosity, which enhances the beer's texture and taste [2]. However, if the protein content is extremely low, the surface tension of beer foam cannot be maintained, and the foam would not last [1,3]. The FAN content is related to the degradation products of proteins. It needs to decrease during fermentation because higher FAN concentrations result in a more turbid beer, which also reduces the stability of the foam $[16,26]$. The FAN content necessary for the fermentation of beer yeast is approximately $20 \mathrm{mg}$ per $100 \mathrm{~mL}$ of wort [3]. In this study, the FAN contents of all of the beers produced were at least $200 \mathrm{mg} / \mathrm{L}$, ranging from 265.54 to $362.06 \mathrm{mg} / \mathrm{L}$. Although the content of bitter substances is high in beer (Table 2), these substances also contribute to enhancing the beer's body feel (Table 3). However, the protein degradation of beers offsets the bitter taste [5]. Here, the bitter taste of malts (8.78 BU) was significantly higher $(p<0.05)$ among all the beers tested, while $A$. awamori KCCM 30790 (2.80 BU) was determined to 3.13 times less bitter $(p<0.001)$ compared to malt. Therefore, the enzymatic activity for protein degradation in rice nuruk (Table 1) was the highest with $A$. awamori, followed by $A$. oryzae CF1003, and then malts with the lowest. Based on a previous study demonstrating that the bitter taste is offset as protein degradation increases [5], the bitter taste was reduced by increasing the amount of rice nuruk added.

The color or chromaticity of beers is affected by phenolic compounds. Chromaticity is also affected by the Maillard reaction while brewing water and during the manufacturing, fermentation, and aging processes [16]. Thus, the color of beer becomes darker depending on the quality of added ingredients and brewing water,
Table 3 Comparison of sensory evaluation in beer with rice nuruk

\begin{tabular}{lccc}
\hline \hline Malt & $\begin{array}{c}\text { A. oryzae } \\
\text { CF1003 }\end{array}$ & $\begin{array}{c}\text { A. awamori } \\
\text { KCCM 30790 }\end{array}$ \\
\hline Color & $10.69 \pm 3.09^{\mathrm{al}}$ & $7.44 \pm 3.14^{\mathrm{b}}$ & $5.75 \pm 2.57^{\mathrm{c}}$ \\
Flavor & $8.63 \pm 3.61^{\mathrm{a}}$ & $6.88 \pm 3.61^{\mathrm{c}}$ & $7.13 \pm 3.88^{\mathrm{b}}$ \\
Taste & $6.56 \pm 3.93^{\mathrm{c}}$ & $8.63 \pm 3.44^{\mathrm{a}}$ & $7.31 \pm 4.29^{\mathrm{b}}$ \\
Texture & $7.81 \pm 2.32^{\mathrm{b}}$ & $8.25 \pm 3.49^{\mathrm{a}}$ & $6.31 \pm 3.09^{\mathrm{c}}$ \\
Overall acceptability & $7.38 \pm 4.40^{\mathrm{b}}$ & $8.06 \pm 3.04^{\mathrm{a}}$ & $7.31 \pm 3.68^{\mathrm{c}}$ \\
\hline
\end{tabular}

${ }^{1)}$ Values are mean \pm SD $(n=3)$, different letters within the same column differ significantly $(p<0.05)$

the delay in manufacturing, filtering, and fermentation processes; and excessive heating $[3,17]$. The $\Delta \mathrm{E}$ values for comparing the chromatic difference between beer samples revealed that the color of the beers made with rice nuruk was significantly paler, and the yellowness value was lower compared to malt beer's $(p<0.05)$.

\section{Sensory evaluation of beer}

Table 3 shows the results of the sensory evaluation for all of the beers. The taste (8.63), texture (8.25), and overall balance (8.06) were significantly different in beers containing A. oryzae CF1003. Meanwhile, the color (10.69) and scent (8.63) were significantly different in malt beer $(p<0.05)$. Thus, from a sensory perspective, beers containing $A$. oryzae CF1003 are the better option.

This study investigated the enzymatic activity of rice nuruk, prepared by selecting strains that would be suitable as a partial substitute for malts in beer production. The characteristics of beers using rice nuruk were compared with those of malt beer. Overall, the enzymatic activity of rice nuruk was significantly higher than 
that of malt due to the brewing fungi. Saccharogenic power and glucoamylase activity were higher in A. awamori KCCM 30790, A. usamii KCTC 6957, and $A$. oryzae CF1003, while the $\alpha$-amylase activity was higher in $A$. oryzae CF1003. The carboxypeptidase activity was extremely high in $A$. usamii KCTC 6959, 6954, and 6958 , which suggests the possibility of an excess amino acid content in manufacturing beers. In the beers produced using only malts, the $\mathrm{pH}$, acidity, alcohol content, amino acid content, FAN, chromaticity, and volatile acid content were significantly higher than those of the rice nuruk beers. However, beers containing $A$. oryzae CF1003 received the highest scores during sensory evaluation (taste, texture, and overall balance). They were further determined to be within the adequate range of the usual fermentation products [3]. These results show that rice nuruk using A. awamori KCCM 30790 and rice nuruk using A. oryzae CF1003 are adequate as partial substitutes for malts in beer production in terms of enzymatic activity and sensory terms, respectively. Therefore, rice nuruk can resolve the insufficient number of enzymes with other substitutes for malts during the saccharification process. As a result, a high-quality rice beer with differentiated taste and quality could be manufactured using rice nuruk.

Acknowledgments This work was carried out with the support of the Research Program for Agriculture Science \& Technology Development (Project No. PJ01260102), Rural Development Administration, Republic of Korea.

Conflict of interest The authors declare no conflict of interest.

\section{References}

1. Jeong C, Park CS, Yeo SH, Jo HC, Noh BS (2016) Brewing Science. Kwangmoonkag, Seoul, Korea, pp 158-159. http://lib.mafra.go.kr/ Search/Detail/39821. Accessed 2 April 2020

2. Lee SK, Park JY, Park HY, Choi HS, Cho DH, Oh SK, Kim HJ (2017) Evaluation of quality characteristics of beer by addition of rice rate. Korean J Food Preserv 24(6): 758-763. doi:10.11002/kjfp.2017.24.6.758

3. Sung SA, Lee SJ (2017) Physicochemical and sensory characteristics of commercial fermented beers. Korean J Food Sci Technol 49(1): 35-43. doi:10.9721/KJFST.2017.49.1.35

4. Kwon YA, Lee KG, Hong KW, Lee SJ (2012) Improving qualities of rice beer using enzymes and amino acids. Food Eng Prog 16(2): 151-156

5. Lee WJ, Cho MK, Chung KM (1995) Quality characteristics of Korean rice as brewing adjunct. Korean J Food Sci Technol 27(4): 516-519

6. Hyeun SK, Kwon YA, Lee SJ (2012) Quality characteristics of brewed beer with rice adjunct. Food Eng Prog 16: 139-144

7. Kim JS, Lee JH, Chang YE, Kim GC, Kim KM (2013) The quality characteristics of rice mash by mixing ratios of rice and rice koji. $\mathrm{J}$ Korean Soc Food Sci Nutr 42(2): 2035-5041. doi:10.3746/jkfn. 2013.42.12.2035
8. Baek SY, Kim JY, Yun HJ, Choi JH, Choi HS, Jeong ST, Yeo SH (2011) Quality characteristics of makgeolli and nuruk grain inoculated with Aspergillus oryzae N041. J East Asian Soc Dietary Life 21(6): 877-881

9. Han EH, Lee YS, Noh BS, Lee DS (1997) Volatile flavor component in mash of takju prepared by using different nuruks. Korean J Food Sci Technol 29(3): 563-570

10. Baek CH, Baek SY, Mun JY, Choi HS, Kang JE, Jung ST, Yeo SH (2016) Quality characteristics and preparing of solid starter using fungal strains for takju. Korean J Food Preserv 23: 797-803

11. Kikkoman Corporation. Saccharogenic power measurement kit. Product information. http://biochemifa.kikkoman.co.jp/products/detail/?id=11180. Accessed 9 April 2020.

12. Sugimoto T, Shoji H (2012) Indigestible dextrin is an excellent inducer for $\alpha$-amylase, $\alpha$-glucosidase and glucoamylase production in a submerged culture of Aspergillus oryzae. Biotechnol Lett 34(2): 347351. doi:10.1007/s10529-011-0777-3

13. Kikkoman Corporation. Acid carboxypeptidase measurement kit. Product information. http://biochemifa.kikkoman.co.jp/products/detail/?id=11200. Accessed 9 April 2020.

14. Encyclopedia Chimica (1964) Kyoritsu Shuppan Co., Tokyo, Japan, pp. $11,110,811,847$

15. National Research Institute of Brewing. About "Liquor Research Institute Standard Analysis Method.” nrib.go.jp/bun/nribanalysis.htm. Accessed 3 April 2020

16. Ha SJ, Yang SK, In YW, Kim YJ, Oh SW (2012) Changes in microbial and physicochemical properties of single-brewed makgeolli by high hydrostatic pressure treatment during fermentation. J Korean Soc Food Sci Nutr 41(8): 1176-1181. doi:10.3746/jkfn.2012.41.8.1176

17. Miller GL (1959) Use of dinitrosalicylic acid reagent for determination of reducing sugar. Anal Chem 31(3): 426-428. doi:10.1021/ac60147a030

18. Park ES, Lee SM, Park KY (2018) In vitro anti-obesity effects of kimchi prepared with solar salts without bittern on 3T3-L1 adipocytes. J Korean Soc Food Sci Nutr 47(2): 229-234. doi:10.3746/jkfn.2018.47.2.229

19. Koh JS (2005) Brewing Engineering. Yuhan Publishing Co., Seoul, Korea. pp 60-70, 90-91

20. Kim HY, Kim SK (2015) Establishment of the manufacturing conditions of hyssop (Hyssopus officinalis)-rice drink. Korean J Food Preserv 22(3): 354-352

21. Jung SJ, Chung CH (2017) Production and properties of ale beer nuruk, a Korean fermentation starter. Korean J. Food Sci Technol 49(2): 132140. doi:10.9721/KJFST.2017.49.2.132

22. Kim SC, Kim HS, Kang YJ (1999) Changes of components in the riceporridge fermented by nuruk. J Korean Soc Food Sci Nutr 28(5): 10171021

23. Kim YR, Moon ST, Park SK (2008) Effects of yeast strains and fermentation temperatures in production of hydrogen sulfide during beer fermentation. Korean J Food Sci Technol 40(2): 238-242

24. Erasmus DJ (2005) Production of acetic acid by Saccharomyces cerevisiae during ice wine fermentations. Ph. D thesis, University of British Columbia, Vancouver, Canada

25. Kim JY, Sung KW, Bae HY, Yi YH (2007) pH, acidity, color, reducing sugar, total sugar, alcohol and organoleptic characteristics of puffed rice powder added takju during fermentation. Korean J Food Sci Technol 39(3): 266-271

26. Brányik T, Vicente AA, Dostálek P, Teixeira JA (2005) Continuous beer fermentation using immobilized yeast cell bioreactor systems. Biotechnol Prog 21(3): 653-663. doi:10.1021/bp050012u 